\title{
COMPARISONAL ANALYSIS OF THE CONCEPT OF TRADITIONAL AND MODERN MUDHARABAH BETWEEN BOOK OF FATH AL-MU'IN AND THE FATWA OF THE NATIONAL SYARI'AH COUNCIL (DSN) OF THE INDONESIAN ULEMA COUNCIL (MUI)
}

\author{
Helmi Maulana \\ Program Doktor Universitas Islam Negeri (UIN) Sunan Kalijaga, Yogyakarta \\ Email: helmi.maulana@gmail.com \\ Mela Inalia Rahmah \\ Institut Agama Islam Darussalam (IAID) Ciamis-Jawa Barat
}

Received: 2 Dec 2019

Accepted: 19 Mar 2020

\begin{abstract}
The purpose of this study was to compare the concept of mudharabah fatwa of the National Syari'ah Council (DSN) of the Indonesian Ulema Council (MUI), and the Kitab Fath al-Mu'in by Sheikh Zainuddin bin Abdul Aziz al-Malibari. The methodology used is the descriptive qualitative method, which is a research method that is directed to describe the results of research as it is based on a literature study. The study results indicate that (a) the concept outlined in the DSN Fatwa is a legal product (ijma') of Muslim scholars and scholars who are members of the MUI which presents mudharabah rules that Islamic financial institutions must practice. (b) According to the book of Fath al-Mu'in, qiradh is a cooperative transaction in the business world with profits based on an agreement in the contract illustrated with interpersonal coverage, the actors do not describe the collaborative activities carried out between groups. (c) In principle, the concept of Qirâd in the book of Fath al-Mu'in and the concept of Mudharabah in the Fatwa of DSN MUI is the same. The difference lies in the actor or party making the contract. They will create a concept that will be different from the understanding, provisions, terms and pillars, profit provisions, dispute resolution, and the legal side.
\end{abstract}

\begin{abstract}
Abstrak
Tujuan penelitian ini adalah untuk mengetahui perbandingan konsep mudhârabah fatwa Dewan Syari'ah Nasional (DSN) Majelis Ulama Indonesia (MUI), dan Kitab Fath al-Mu'in karya Syekh Zainuddin bin Abdul Aziz al-Malibari. Metodologi yang digunakan adalah metode kualitatif deskriptif, yaitu suatu metode penelitian yang diarahkan untuk memaparkan hasil penelitian apa adanya dengan berbasis studi kepustakaan. Hasil penelitian menunjukkan bahwa (a) konsep yang dituangkan dalam Fatwa DSN adalah produk hukum ( $\ddot{j m a} a^{\prime}$ ) ulama dan cendikiawan muslim yang tergabung dalam MUI yang menyuguhkan aturan mudhârabah yang harus dipraktikkan oleh lembaga keuangan syari'ah. (b) Menurut kitab Fath al-Mu'in, qiradh adalah transaksi kerjasama dalam dunia usaha dengan keuntungan berdasarkan kesepakatan dalam akad diilustrasikan dengan cakupan antar pribadi, pelaku tidak menggambarkan kegiatan kerjasama yang dilakukan antar kelompok. (c) Secara prinsipil, konsep Qirâd dalam kitab Fath al-Mu'in' dan konsep Mudhârabah dalam Fatwa DSN MUI sama saja. Perbedaannya terletak pada pelaku atau pihak yang melakukan akad, kemudian akan membuat konsep yang akan berbeda dari mulai pengertian, ketentuan, syarat dan rukun, ketentuan keuntungan, penyelesaian sengketa, serta dari sisi hukumnya.
\end{abstract}


Keywords: Mudharabah, Fatwa DSN dan Fath al-Mu'in'

\section{Introduction}

Basically, every human being in his activities, both worldly and in the hereafter, cannot be separated from the goals (maqasyid) of what humans will get after these activities, with various kinds of differences in the perspective of humans themselves on the essence of what humans want to get, so it is not rare. The process to get to the maqosyid goal may also be colorful. One example is in socio-economic activities; many of the people themselves are trapped in this matter, prioritizing the fulfillment of personal rights and ignoring other people's rights, whether those rights are in the form of individuals or the general public. However, Islam is a religion in which rahmatan lilâ'lamin regulates the entire order of human life, so that the norms imposed by Islam can provide a solution of justice and honesty in terms of achieving human goals rather than their activities, so that there will be no social inequality between humans themselves. .

So it is not uncommon among humans who are very capable of finding verses in the Holy Qur'an that encourage trade and commerce. Islam very clearly states that there should be no obstacles to honest and lawful trade and business so that everyone can earn income. , provide for the family, and give alms to less fortunate people. Referring to the legal principles that Islamic teachings have established in terms of commercial transactions, namely: sales (bay'), Rent (ijarâh), Gifts (grants), Loans (a'riyah). These four types of partnerships are applied to a wide variety of special transactions. One of them is a mudharabah partnership. Looking at the brief discussion above, the author is interested in discussing more about the concept of Mudharabah transactions.

In everyday life, it is impossible to separate from economic activity. This term is often heard and is often found in human life including at home, at school, and in the community. Everyone is busy in their daily life fulfilling various unlimited necessities of life, both in goods and services and even money.

Meeting the needs are pursued through employment opportunities as traders, farmers, civil servants, entrepreneurs, laborers, and other jobs. The effort made is a manifestation of Allah's command to seek sustenance that has been provided for His creatures. Allah swt commands humans to always try and prioritize the life of this world in addition to the life of the hereafter. As His word in Q.S. Al-Qhashash, 28: 77. "And seek in what Allah has bestowed upon you (happiness) in the hereafter, and do not forget your share of worldly (pleasures) and do good (to others) as Allah has done good to you, and do not do mischief in (your face) earth. Verily, Allah does not like those who make mischief." (Q.S. Al-Qasas, 28:77)

As long as humans use their minds and energy, they will not lose their livelihood because there are many ways that humans can do to fulfill their needs, through all the facilities that already exist and are spread out on the surface of nature, either by themselves or by joint or joint ventures, depending on the scale of the business. Among the ways that can be done by someone who wants to open or start a business but the capital they have is insufficient or non-existent, they can invite their colleagues to cooperate in business investment. This activity in terms of fiqh is called mudhrâbah.

However, recently the term mudharabah contract financing has been found. This term was born on the ijtihad of the Indonesian Ulema Council, which was stipulated in Fatwa No. 7/DSN-MUI/IV/2000. Basically, the Indonesian Ulema Council is also aware that in mudharabah there is no term for financing the mudharabah contract. However, on the basis of considerations of various factors, the Indonesian Ulema 
Council stipulates the existence of financing in mudharabah. Thus the financing in the mudharabah contract is a pure ijtihad of the Indonesian Ulema Council. This ijtihad is of course local (Indonesian), because it is not necessarily that the Ulama as a whole have ijtihad in this regard. In addition to ijtihad on the cost of the mudharabah contract, the Indonesian Ulema Council also ijtihad in the distribution of results, which has been a matter of debate among scholars. Some say that the profit sharing from the mudharabah model must be divided before deducting operational costs. But not a few who dispute this statement. According to him, he denied that the profit sharing was carried out after deducting operational costs.

The Indonesian Ulema Council (MUI), in building arguments in determining the financing of the mudharabah contract, is based on understanding religious texts, which include the Qur'an, al-Hadith and the rule of law (fiqh). The verse of the Qur'an that is used as an argument (Q.S. An-Nisa, 4: 29). "O you who believe, do not falsely eat each other's wealth, except by way of commerce which is carried out with mutual consent between you. And do not kill yourselves, verily Allah is most merciful to you." (Q.S. AnNisa, 4:29)

In this verse found the word an taradhin. An tarâdhin means willingness. This verse as a whole talks about how to get wealth by cooperation. The second verse of the Qur'an which is used as the basis for financing mudharabah by the Indonesian Ulema Council (MUI) is (Q.S. Al-Maidah, 5: 1). "O you who believe, fulfill these contracts. And cattle are lawful for you, except those that are to be read to you. That is by not justifying hunting while you are doing Hajj. Verily, Allah sets the laws according to His will. (Q.S. Al-maidah, 5:1)

In this verse, the word bi al-Uqûd in the plural form of 'aqdun in Indonesian means contract. The word 'aqdun originally meant binding something with something so that it did not become part of it and did not separate from it. Buying and selling, for example, is a form of contract, which makes the purchased item the property of the buyer, he can do anything with the item, and the owner of everything, namely the seller with the sale and purchase contract, no longer has the slightest authority over the goods he has sold. M. Quraish Shihab, 2000: 125).

\section{Theoretical Review}

Etymologically, mudharabah comes from the word al-dharb which means traveling or walking. In addition to al-dharb, it is also called qirâdh from al-qardhu which means al-qath'u (pieces). The meanings of the two are relevant to each other: First, because those who carry out yadhrîb fil ardhi (walking on earth) business by traveling to trade, he is entitled to profit because of his business and work. Second, because each person who is in association with yadhribû bi sahmin (taking part in the profits).

In terminology, mudharabah is an agreement contract between two parties, one of which is the owner of capital given to the other party to be developed, and the profits are divided in two according to the agreement. The term mudharabah put forward by the scholars is as follows: (1) According to the fuqohâ', mudharabah is a contract between two parties to bear each other, one party surrenders his property to another party to be traded with a predetermined share of profits, such as half or a third with predetermined conditions. (2) According to Hanafiyah, mudharabah is looking at the purpose of two parties who have a contract who are united in profit (profit), because the property is handed over to the other. The other has the service of managing the property. Mudharabah are: 


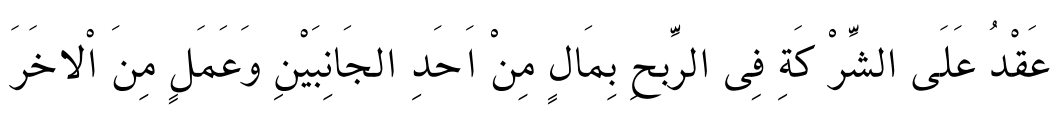

Shirkah contract in profit, one party is the owner of the property and the other is the owner of the service

(3) According to Malikiyyah, mudharabah is:

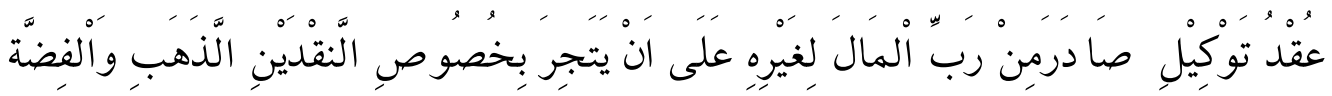

Representative contract, where the owner of the property issues his property to another to be traded with a specified payment (gold and silver)

(4) According to Syafí'iyah, mudharabah is:

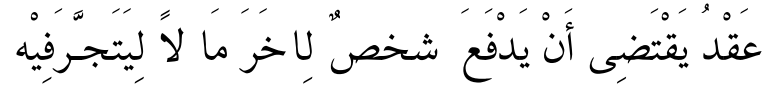

A contract that determines one person to hand over his property to another to be encumbered

From a legal point of view, there are two kinds of mudharabah law: (1) a. Mudharabah Fasid. If in implementing the mudharabah there are conditions that are not met, then the mudharabah can be classified as fasid or damaged mudharabah. The fuqaha agree that the law of the damaged mudharabah is the cancellation of the mudharabah and the return of the capital assets to the owner as long as the assets have not been used up. (2) Mudharabah Sahih. If, in carrying out the mudharabah contract, all the conditions and pillars have been fulfilled, then it is called a sahih mudharabah. Valid mudharabah includes: (a) About the power of mudharib. The jurists have agreed that in fact the one who is given capital is the mudharib as a representative (trust holder) for the owner of the capital when a transaction occurs, because everything he does has received permission from the owner of the capital and that is actually the meaning of the word representative. If the mudharabah is canceled due to several valid reasons, the mudharabah is categorized as ijarah and the executor is the seller of services. (b) Efforts made by mudharib in mudharabah. The legal action of mudharab varies depending on the type of mudharabah. If absolute mudharabah is a contract of the surrender of capital by shâhibul mal to mudhârib without specifying the type of business, place, time, nature, and people who become business partners. Meanwhile, mudharabah muqayyadah is a mudharabah contract in which the owner of the capital determines the type of business, time, and so on. (c) Something that cannot be done by mudharib. In mudharabah there are several provisions that cannot be carried out by mudharabs unless there is a text that allows it, for example:

1) Mudharib should not be in debt to increase capital.

2) b) Mudharib is not allowed to buy goods through debt even though the shâhibul mal allows it.

3) Mudharib is not allowed to buy goods over the mudharabah capital, whether paid directly or indirectly because there is a prohibition against taking profit from something that is not owned.

4) Mudharib is also not allowed to give assets to other people for mudharabah or association with him, or mix it with his own property or with other people's property unless, if the owner of the capital says "do it according to your opinion" or he permits to manage it.

5) Mudharib repeats his mudharabah

First, the Hanafi school thinks that it is not permissible for the mudharab to repeat the mudharabah of the property with another person, unless permitted by the owner of the property. Second, the Maliki school says that the manager (âmil) is the guarantor (dhâmin) if he lends the property without the owner's permission, meaning 
that it is delegated to others to be managed and the profit at that time belongs to the second manager and owner of the property, there is no profit for the first manager because of the gain. A loan is a bonus, and it is not entitled except with perfect management.

The mudharabah contract will be void or terminated if the following things occur: Cancellation and prohibition of using capital (capital removal) Mudharabah becomes void by cancellation, prohibition of using capital or removal if there are conditions for cancellation or prohibition, namely mudharab knowing the cancellation and the prohibition is in the form of capital cash or non-cash at the time of the cancellation and prohibition. Meanwhile, if the mudharib knows about the removal and the capital is in the form of merchandise, he may sell it so that it becomes cash and there is profit. Shâhibul mal should not forbid it, because that's the form of the cancellation of this right was agreed upon by the scholars of the four schools of thought.

a. The death of one of the two

If the shâhibul mal or mudhârib dies, the mudharabah is canceled according to jumhur, because mudharabah includes wakalah. Wakalah is canceled with the death of the person who represents or his representative. Mudharabah is void, whether the worker knows the death of the owner of the capital or not, because death is a law that aborts it does not depend on knowledge as in wakalah. Malikiyah is of the opinion that the mudharabah is not invalidated by the death of one of the two and the heirs of the property electorate continue the mudharabah if they are trusted people.

b. One of them both went crazy

Mudharabah is canceled because of madness cancels the ability to do muamalat and every person who cancels wakalah also cancels mudharabah, such as fainting and prohibition against the owner of capital. As for the prohibition against workers because they are stupid, according to Hanafiyah, they are not removed, because they are like mumayyiz children and mumayyiz can receive wakalah from other people. Likewise with stupid people.

\section{c. The owner of the capital becomes an apostate}

Suppose the shâhibul mal is killed for apostasy or joining the war and the judge confirms his participation. In that case, the mudharabah is canceled on the day of his apostasy according to Abu Hanifah, because joining the battlefield is the same as death, and death causes the loss of the ability of the owner of capital. If the worker apostates, the mudharabah continues, because of the power of the owner of capital, even though the worker has bought and sold and made a profit, then he is killed for apostasy or dies or goes to war, then everything he has done is permissible and the profits are divided for both, as agreed upon because the work of the apostate is legal because he is a human being who can distinguish (mumayyîz) without any flaws in him.

\section{$\mathrm{d}$. The destruction of mudharabah property in the hands of workers}

Mudharib is negligent in maintaining property, or doing something that is contrary to the purpose of the contract. In such a condition, the mudharabah contract is void. Likewise, mudharabah is canceled if the worker destroys the capital or spends it or is handed over to someone else and then destroyed. The worker is not entitled to buy any capital for mudharabah. (Abdul Gofur, 2008: 128).

The school scholars agree that mudharabah is permissible based on the Qur'an, sunnah, ijma' and qiyas. This is because the mudharabah contract aims to help each other between the owner of the capital and someone who is an expert in turning money. Many people have capital but are not good at managing and earning their money, and vice versa while many have expertise in trading but do not have capital. On the basis of 
mutual assistance in managing capital, Islam provides an opportunity for mutual cooperation between the owner of the capital and someone who is skilled in managing and producing that capital. (H. Juhaya, 2012: 67)

Thus, the mudharabah contract is covered by general arguments that justify a person or an institution to trade and seek lawful profits, as well as arguments that justify all things that are beneficial or whose benefits are greater than the harm. In general, the basic foundation of shari'ah mudharabah reflects the recommendation to do business, this can be seen in the following verses and hadiths:

a. Al-Qur'ân

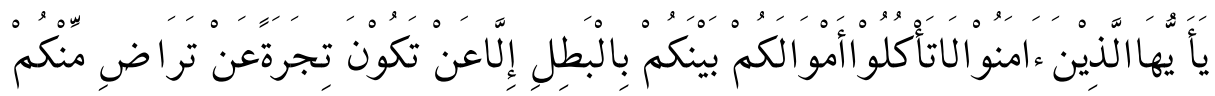

"O ye who believe ! Do not eat (take) each other's property with falsehood, except by way of commerce that applies voluntarily between you...” (QS. An-Nisa', 4: 29)

b. Al-Hadîts

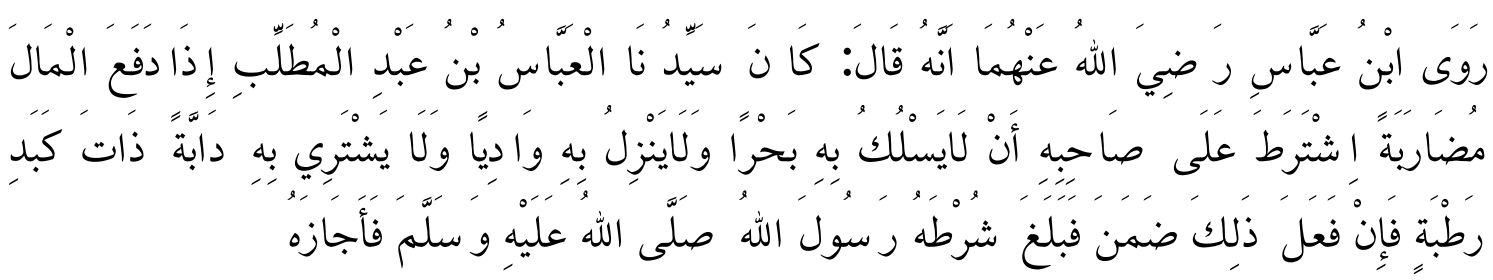

"It was narrated from Ibn Abbas that Sayyidina Abbas bin Abdul Muttalib when giving funds to his business partners in a mudharabah way, he requires that the funds are not carried across the sea, down a dangerous valley, or buy livestock. If it violates these regulations, the person concerned is responsible for the funds. These conditions were conveyed to the Messenger of Allah. and the Messenger of Allah allowed it." (H.R. Thabrani)

c. Ijma

It is narrated that a number of companions gave (to people, mudharabs) the property of orphans as mudharabah and no one denied them. Therefore, it is seen as ijma' (Antonio, 2001: 175).

\section{d. Qiyas}

As for qiyas mudharabah equated with musyaqah. Apart from humans, there are the poor and the rich. On the other hand, few poor people want to work, but do not have the capital. Thus, the existence of mudharabah is intended, among other things, to meet the needs of the two groups above, namely for the benefit. Furthermore, in the rules of ushul fiqh:

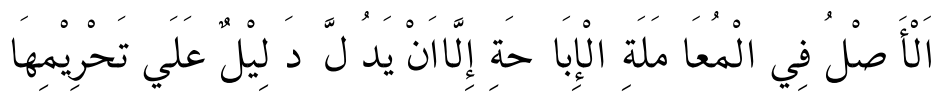

The original law in all forms of muamalah is permissible unless there is evidence that forbids it.

1) Mudharabah Mutlaqah is where the shâhibul mal gives the manager (mudharib) full flexibility to use the funds in a business he deems good and profitable. However, the manager is still responsible for managing it in accordance with normal healthy business habits (uruf).

2) Mudharabah Muqayyadah is where the fund owner determines the terms and restrictions for the manager in the use of the fund with a period of time, place, type of business and so on. 
There are three pillars of mudharabah according to the view of the majority of scholars, namely 'aqid (owner of capital), 'amil/mudharib (manager), ma'qud a'laih (capital, work and profit), and the last is shighat (ijab and qabul). The pillars of mudharabah will be perfect if they fulfill the following pillars: investors (shâhibul mal), manager (mudharib), there is a business that is shared, profit ratio, there is consent and qabul.

\section{Method}

The research data sources consist of primary data sources and secondary (supporting) data sources. Primary data sources are the main data sources used by the author in this study. Usually this primary data source can be from books, articles, or other works written directly by the character to be studied. The primary data source that the author uses is the work of the figures studied, namely the book Fath al-Mu'in' by Shaykh Zainuddin bin Abdul Aziz al-Malibary and the Fatwa of the National Syari'ah Council (DSN) of the Indonesian Ulema Council (MUI) No. 07/DSN-MUI/IV/2000. Secondary data in the form of several works related to the Mudharabah contract, including the translation of Syarah Fath al-Mu'in' by Shaykh Zainuddin bin Abdul Aziz al-Malibari al-Fannani, and other general books related to the object of study. In collecting data, the author does it by searching and collecting books, primary data and secondary data. After collecting data, the writer conducts a study and relates it to related data to find the research materials (Brata, 1995: 72). Because this research is library research, the data collection technique used in this study is literary data collection, namely by collecting library materials that are continuous (coherent) with the object of discussion under study. The data in the literature is collected and processed by:

1) Editing, namely re-examination of the data obtained, especially in terms of completeness, clarity of meaning and coherence of meaning between one another.

2) Organizing, namely compiling the data obtained with a predetermined framework.

3) The discovery of research results, namely conducting further analysis of the results of data compilation using predetermined rules, theories and methods so that certain conclusions (inferences) are obtained which are the results of answers to the formulation of the problem. (Sunggono, 1997: 112)

Triangulation is a technique used to test the trustworthiness of the data (checking the validity of the data or verifying the data), or in other terms known as "trustworthiness" by utilizing other things that exist outside the data to check or as a comparison to the data obtained. has been collected. In descriptive research, triangulation is the method used to verify as long as the research is carried out until the data is analyzed and reports are written. In other words, triangulation is the process of testing the validity of the data. (Moleong, 2014: 137)

In this research, the data validity technique used triangulation technique. The answer from an informant obtained from the interview was checked again with documentary data, then with other documents, whether written here could be through literature study and observation. Triangulation technique is a technique of checking the validity of data that utilizes something other than the data for matching purposes or as a comparison against the data. (Lexy J. Moleong, 2007: 330). The triangulation technique used in this study is a triangulation technique that utilizes observations with documentation data and observations as well as literature studies conducted through the results of this research. Written documents (including text documents) are rechecked for truth through documentary data and historical tracing or through 
literature studies and observations of places where texts are produced to determine text production, namely social cognition and context.

\section{Results and Discussion}

It is clear in principle that the concept of Qiradh in the book of Fath al-Mu'in' and Mudharabah in the Fatwa of the MUI DSN are the same, only the difference lies in the actors or parties who carry out the contract, namely between institutions that are not only individuals but are legal entities as mentioned in the understanding according to the Fatwa of the National Sharia Council of MUI and individuals as described in the book Fath al-Mu'in'. From that understanding, a concept will be made that will be different from the provisions, terms and pillars as well as a view of the benefits of business results. To make it clearer, the author describes some of the differences and similarities between the concepts of Qirâd and Mudharabah Financing: In the book Fath al-Mu'in' the author explains that the actors of the cooperation contract are individuals with capital using legal assets or money with the profits being divided equally. Meanwhile, in the DSN Fatwa, the perpetrators or contracting parties are not only individuals but also groups and institutions that are legal entities that are technically legal objects, with benefits that have been agreed upon in the contract.

In the book of Fath al-Mu'in there are several provisions that must be considered by those who have a contract, including: (1) Qiradhh is valid when it concerns legal money or gold and silver currency even though the government has withdrawn the appeasement in power in the area. (2) It is not valid to use assets other than money, gold and silver, because qirâdh is a transaction that is not clear between profit and loss. (3) Counterfeit currency, gold and silver that have not been minted into currency such as gold and silver bars or jewelry are not valid to be used as capital in qirâdh. (4) Gold and Silver that have been minted into invalid currency become a transaction tool if they are mixed with other metal elements and reduce the value of the currency. But if it has become a legal or official medium of exchange, then gold and silver mixed with other metal elements are valid as a means of transaction in qirâdh.

Qiradh is valid even if it is only with a sighat ijab, but it is better to be accompanied by a qabul greeting from the recipient of the capital with words that can be interpreted by both parties.

Qiradh is valid if the capital owner and entrepreneur are said to be valid to carry out tasharuf as valid in buying and selling. If you look at the Fatwa of the MUI National Syari'ah Council (DSN) Number 7/DSN-MUI/IV/2000 concerning Mudharabah Financing (Qirâd), there are several provisions in it as described above regarding provisions that must be considered by shahib al-mal, namely Financial Institutions Syari'ah (LKS) and Mudharib or entrepreneurs, so that the transactions carried out are legal according to Islamic law and legal law according to the state.

While the terms and pillars contained in the book of Fath al-Mu'in' and the Fatwa of the MUI National Syari'ah Council (DSN) are not much different, there are several things that distinguish them, because the position of financiers or shohibul mal is a legal entity, including shahib al-mal and mudharib. If in the book Fath al-Mu'in' Shaibul mal and Mudharib are competent in law based on Islamic Shari'ah, then if the legal competence referred to in the fatwa of the National Syari'ah Council (DSN) MUI is more comprehensive covering state law, namely laws and laws that applicable in Indonesia, as for legal financial institutions. These namely financial institutions already have permission from the government.

In the book of Fath al-Mu'in' Qirâdh, transactions are valid even if only with an ijab or surrender, in the fatwa of the National Syari'ah Council (DSN) of the Indonesian 
Ulema Council (MUI) consent and qabul are strongly emphasized based on applicable rules so that the contract can be accounted for answer legally, so it is important that the contract is in the form of writing that explains the legally valid agreement of the two parties. Likewise in the book Fath al-Mu'in', the fatwa of the National Sharia Council (DSN) of the Indonesian Ulema Council (MUI) states that capital is an item or asset that has a legally valid value, but in the book of Fath al-Mu' in' does not mention that it is invalid if the capital is in the form of cash. Mudharabah contract is a business contract so that the purpose of the cooperation is to gain profit, based on the existing provisions both in the book of Fath al-Mu'in' or in the fatwa of the National Syari'ah Council (DSN) of the Indonesian Ulema Council (MUI), that the provisions must be divided based on an agreement that has been determined in advance and fulfills the principles of justice.

If there is a dispute between the two parties in the mudharabah contract or several things that are considered to violate the applicable rules or laws, Sheikh Zainuddin in the book of Fath al-Mu'in' provides illustrations including: (1) The manager (business owner) is justified on his oath if there is a problem with the goods that are the object of the business. (2) Damage to property or business assets will be borne by the manager if it is proven due to the negligence of the manager. (3) If based on a report that the business results are profitable, then the business manager cancels the report for reasons that are not clear, the revocation of the report is not accepted. (4) If there is a dispute over the percentage of the business, both parties must take an oath on their opinion, and after the qiradh transaction ends, the 'amil (manager) gets a proper wage while the profits become the full rights of the owner of the capital. (5) If the disagreement lies between the status of the amil as a representative or manager, then what is justified is the oath of the owner of the capital and there is no burden to provide wages.

Meanwhile, the settlement if there are problems between the two parties in the mudharabah financing transaction can be resolved based on the agreement and the applicable provisions. However, if it is difficult to resolve amicably in the sense that it cannot be resolved based on deliberation, then a legal route can be taken, because it is clear that the applicable provisions and the agreements made must be legally accountable. Mudharabah (Qirâd) in the Book of Fath al-Mu'in' and the Fatwa of the National Syari'ah Council (DSN) of the Indonesian Ulema Council (MUI) No: 07/DSNMUI/IV/2000 from the Force of Law

The Indonesian Ulema Council (MUI), which is a forum for deliberation of Ulama, zu'ama, and Muslim scholars as well as a protector for all Indonesian Muslims, is the most competent institution in answering and solving every socio-religious problem that always arises and is faced by the community. The Indonesian Ulema Council has also won the trust of the public and the government.

In the economic field, the MUI has established a working instrument, namely the DSN-MUI which specifically handles issues related to the activities of Islamic Financial Institutions (LKS) and Islamic economics, this is stated in the MUI leadership board Decree no. Kep-754/MUI/II/1999 dated February 10, 1999, the duties and functions of the DSN-MUI are to issue a fatwa on sharia economics to serve as a guide for practitioners and regulators. Currently, DSN-MUI has issued 81 fatwas. However, the DSN-MUI itself has not yet known the legal power of the fatwa in positive law so that it is used as the operational basis for Islamic financial institutions. However, not a few DSN-MUI fatwas are absorbed in various laws and regulations, especially in the field of Islamic economics in Islamic financial institutions.

Sainul and Muhamad Ibnu Afrelian (2015: 189) in their journal entitled Legal Aspects of the DSN-MUI Fatwa in the operation of Sharia Financial Institutions, the 
DSN-MUI fatwa is very important in Islamic law. Especially in accommodating legal problems that exist in society with the birth of the sharia economy. In addition, when linked in positive law, the DSN-MUI fatwa has the same position as a doctrine, namely as a reinforcement in the decision of a qadhî in a case. The DSN-MUI fatwa also has the authority and an important role in making laws that are binding and serve as positive laws in order to improve the development of sharia economics in Indonesia.

The legal aspect contained in the DSN-MUI fatwa in operation is the absorption of the DSN-MUI fatwa in various laws and regulations related to the operation of Islamic Financial Institutions. This can be seen from the fatwa which has been transformed into a law. The legal power of the DSN-MUI fatwa is binding in the operations of Sharia Financial Institutions. This can be seen in KMA/o32/SK/IV/2006 concerning the Enforcement of Book II of Guidelines for the Implementation of Duties and Court Administration, the DSN-MUI Fatwa is one of the material laws in resolving cases, especially in the Religious Courts/Shari'ah Courts.

The book of Fath al-Mu'in' is one of the fiqh reference books in which there is ijtihad of scholars which is legally justified according to the laws of syara'. Likewise, the Fatwa of the MUI DSN is the result of the Ijma' and Qiyas of the Indonesian Ulama whose provisions can be justified by Islamic law, but when viewed from the provisions, terms and pillars that exist when there are problems that occur from mudharabah transactions carried out by Islamic financial institutions and the entrepreneur, what is taken is the provisions contained in the Fatwa of the MUI DSN, and the resolution of the problem can be resolved according to positive law in force in Indonesia.

\section{Conclusion}

The concept outlined in the Fatwa of the Sharia Council is a legal product (ijma') of Muslim scholars and scholars who are members of the Indonesian Ulema Council (MUI)-offering Mudharabah rules that must be carried out by sharia financial institutions, of course, which are legal according to applicable laws in the country. Even though it is not directly stated in the fatwa, the law must be upheld by every citizen, because even though it has fulfilled the basic terms and conditions of the mudharabah transaction and is said to be legally valid, mudharabah transactions carried out by agencies or groups will be very difficult to take legal action if problems or disputes occur. So that every transaction is carried out in an administrative order. Meanwhile, by Sheikh Zainudin bin Abdul Aziz Al-Malibari in the book Fath al-Mu'in' about qiradh is a cooperative transaction in the business world with profits based on the agreement in the contract illustrated with the scope of the individual actors, does not describe the cooperative activities carried out between groups or groups. personally caused by the prevailing culture of his day, so that the concept offered is simpler. In principle, the relationship between the concept of Qirâd in the book of Fath al-Mu'in' and Mudharabah in the Fatwa of DSN MUI is the same, only the difference lies in the actors or parties who make the contract, namely between institutions that are not only individuals but are legal entities as mentioned above. in the sense according to the Fatwa of the MUI National Syari'ah Council and individuals as described in the book Fath al-Mu'in'. From that understanding, different concepts will be created starting from the understanding, provisions, terms and pillars, profit provisions, dispute resolution, and the legal side.

\section{REFERENCES}

Agung, Gusti Ngurah.(1990). Metode Penelitian Sosial: Pengertian Dan Pemaknaan Praktis ,Jakarta: Gramedia 
Ali, Mohammad. (1993). Strategi Penelitian Pendidikan.Bandung: Angkasa.

Algoud, Latifa \& Mervyn K. Lewis.(2003). Perbankan Syariah Prinsip-PraktikProspek. Jakarta. PT. Serambi Ilmu Semesta

Anwar, Moch.(2016). Terjemahan Fath al-Mu’in' Jilid 1. Bandung: Sinar Baru Algensindo

Antonio, M. Syafi'i.(2001). Bank Syari’ah dari teori ke Praktik. Jakarta: Gema Insani

Anshori, Abdul Gofur.(2008). Penerapan Prinsip Syari'ah Dalam Lembaga Keuangan Lembaga Pembiayaan dan Perusahaan Pembiayaan.Yogyakarta. Pustaka Pelajar

Arifin, Zaenal. (2007). Realisasi Akad Mudharabah dalam Rangkapenyaluran Dana dengan Prinsip Bagi Hasil di Bank Muamalat Indonesia Cabang Semarang. Pasca Sarjana, Program Studi Kenotariatan, Universitas Diponegoro Semarang.

Azwar, Saifuddin.(2007). Metode Penelitian. Yogyakarta: Pustaka Pelajar

Brata, Sumadi surya.(1995). Metodologi Penelitian, Jakarta: Raya Grapindo Persada

Dewan Syari'ah Nasional Majelis Ulama Indonesia.(2006). Himpunan Fatwa Dewan Syari’ah Nasional. Cipayung Ciputat. CV. Gaung Persada

Djuwaini, dimyauddin.(2010). Pengantar Fiqh Muamalah. Yogyakarta. Pustaka Pelajar

Hertanto. (2012) Realisasi Akad Mudharabah dalam Penyaluran Dana di BPR Syariah Amanah di Bekasi. Skripsi. Program Pasca Sarjana, Program Studi Kenotariatan, Universitas Diponegoro Semarang

Karim, Ir. Adiwarman.(2004). Bank Islam Analisis Fiqih dan Keuangan Edisi Dua. Jakarta. PT. Raja Grafindo Persada

Pradja, H. Juhaya.(2012). Ekonomi Syariah. Bandung. CV. Pustaka Setia

Mukhtar.(2013). Metode Praktis Penelitian Deskriptif Kualitatif. Jakarta Selatan. Referensi (GP Press Group)

Moleong, Dr. Lexi.(2014).Metodologi Penelitian Kualitatif Edisi Revisi. Bandung. PT. Remaja Rosdakarya

Sainul dan Muhammad Afrelian. (2015). Asfek Hukum Fatwa DSN-MUI dalam Operasional Lembaga Keuangan Syariah. Jurnal Hukum dan Ekonomi Syari'ah, Vol. 30. No. 02. 172-192.

Sjahdeini, Sutan Remy. (2007). Perbankan Islam dan kedudukannya dalam tata hukum Perbankan Indonesia. Jakarta: PT. Pustaka Utama

Sjahdeini, Sutan Remy. (2014). Perbakan Syari'ah produk-produk dan Aspek-Aspek Hukumnya. Jakarta: .PT. Adhitya Andrebina

Sugiyono. (2015). Metode Penelitian Kuantitatif, kualitatif dan R\&D. Bandung: Alfabeta.

Sutanto, Herry \& Kaherul Umam.(2013). Manajemen Pemasaran Bank Syariah. Bandung: Pustaka Setia.

Sunggono, Bambang. (1997). Metodologi Penelitian Hukum. Jakarta: PT. Raja Grafindo Persada

Suwiknyo, Dwi.(2010). Analisis Laporan Keuangan Perbankan Syari'ah. Yogyakarta. Pustaka Pelajar 
Suwiknyo, Dwi.(2010). Jasa-jasa Perbankan Syariah.Produk-Produk Jasa Perbangkan Syariah. Yogyakarta. Pustaka Pelajar

Umam, Khaerul.(2013). Manajemen Perbankan Syariah. Bandung. CV. Pustaka Setia 